\title{
Poverty and Inequality in Rural Education: Evidence from China
}

Jiayi Shi

https://orcid.org/0000-0003-4215-3374

Xi'an Jiaotong University, China

shijiayi@xjtu.edu.cn

\author{
Peter Sercombe \\ https://orcid.org/0000-0002-6236-0269 \\ Newcastle University, United Kingdom \\ peter.sercombe@newcastle.ac.uk
}

\section{Abstract}

In 1998, the People's Republic of China implemented an education policy, the "School Consolidation Policy", which entailed merging small rural schools with larger ones. It has had a massive effect on rural people across China, and as a result of it, over $60 \%$ of schools in outlying areas have closed. The policy's implementation and effects have received little scholarly attention, despite its scale and consequences. This article investigates the policy, drawing on the nexus between critical discourse analysis and an ethnographical study conducted from 2007 to 2018. The article reviews trajectories and critical junctures shaping educational change in one rural community in north-western China, as an example of broader changes that have been occurring across the country. This is presented through four thematically interrelated episodes, over a 10-year period, illustrating the conception of the policy, its local interpretation and implementation, and its consequences as perceived by stakeholders. The recontextualisation of rural education is part of the policy, as expressed in political discourse, and is examined together with its wider impacts. Attention is paid to the local adoption of the policy at different levels of government and the challenges faced by villagers in rural China in their efforts to capitalise on educational opportunities and secure a measure of social mobility. Consequences of the policy's implementation are analysed and include rising educational inequality, social marginalisation and a lack of social mobility prospects for families affected.

Keywords: School Consolidation Policy; Chinese rural education; education-poverty trap; educational inequality

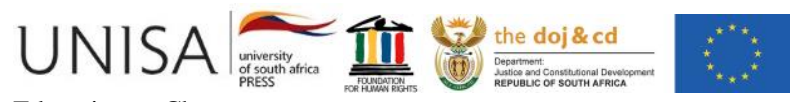

Education as Change https://upjournals.co.za/index.php/EAC

https://doi.org/10.25159/1947-9417/4965

Volume 24 | $2020 \mid \# 4965$ | 26 pages 


\section{Introduction}

Under the movement of educational reform in China, seeking modernisation and competitiveness (State Council 1998), backwardness, isolation and poverty take their toll on villages that are socially, politically, and economically vulnerable. From 2001 to 2012, the Chinese central government implemented policies attempting to redistribute education resources to cope with administrative and fiscal changes in the national education system. One of those policies was the School Consolidation Policy (chedianbingxiao); it was later interpreted by national media and the public as meaning the "merger of small rural schools with larger ones", and resulted in the closure of over $60 \%$ of Chinese rural schools (Ministry of Education [MoE] 2002; 2013). In 2007, we began an ethnographic study of the educational lives of the inhabitants of Jikan (see Figure 1), a village in the inner north-west of Shaanxi Province, to witness what villagers experience in their quest to capitalise on educational opportunities and gain some social mobility. We consider institutionalised discourse over a 10-year period through four interrelated episodes demonstrating the educational trajectories and life chances of Jikaners. The integration of CDA and ethnography (cf. Krzyżanowski 2011) allows for the analysis of issues salient to an understanding of the SCP's consequences in Jikan and other rural areas in China; by considering relevant state documents and local perceptions of the effects of the SCP, the study reveals educational inequality, the marginalisation of society's lower echelons, and a consequent lack of social mobility for rurally based children.

\section{The School Consolidation Policy (SCP): Initiatives and Controversies}

In 1998, the Chinese State Council (SC) issued Decisions on Deepening Education Reform and Fully Promoting Quality Education (hereafter, Decisions) defining the landscape of Chinese compulsory education. To improve administrative and fiscal efficiency in education, it urged reforms that simplify administration across China. The devolution of management means local governments have more power to develop basic education in ways they choose. The State Council and Ministry of Education (MoE) control policymaking, planning, and regulations at national level. Provincial-level authorities have been tasked to enact regulations and allocate funds to counties. County education departments are meant to supervise education and manage their senior middle schools, teacher training colleges and exemplary primary and junior middle schools. To manage the remaining schools, township governments rely on funds distributed by county governments and these compensate for deficiencies in township revenues. Changes in the education system have shifted rural compulsory education administration from village and township level to county level (see Figure 1 for the administrative structure of the Chinese education system). 


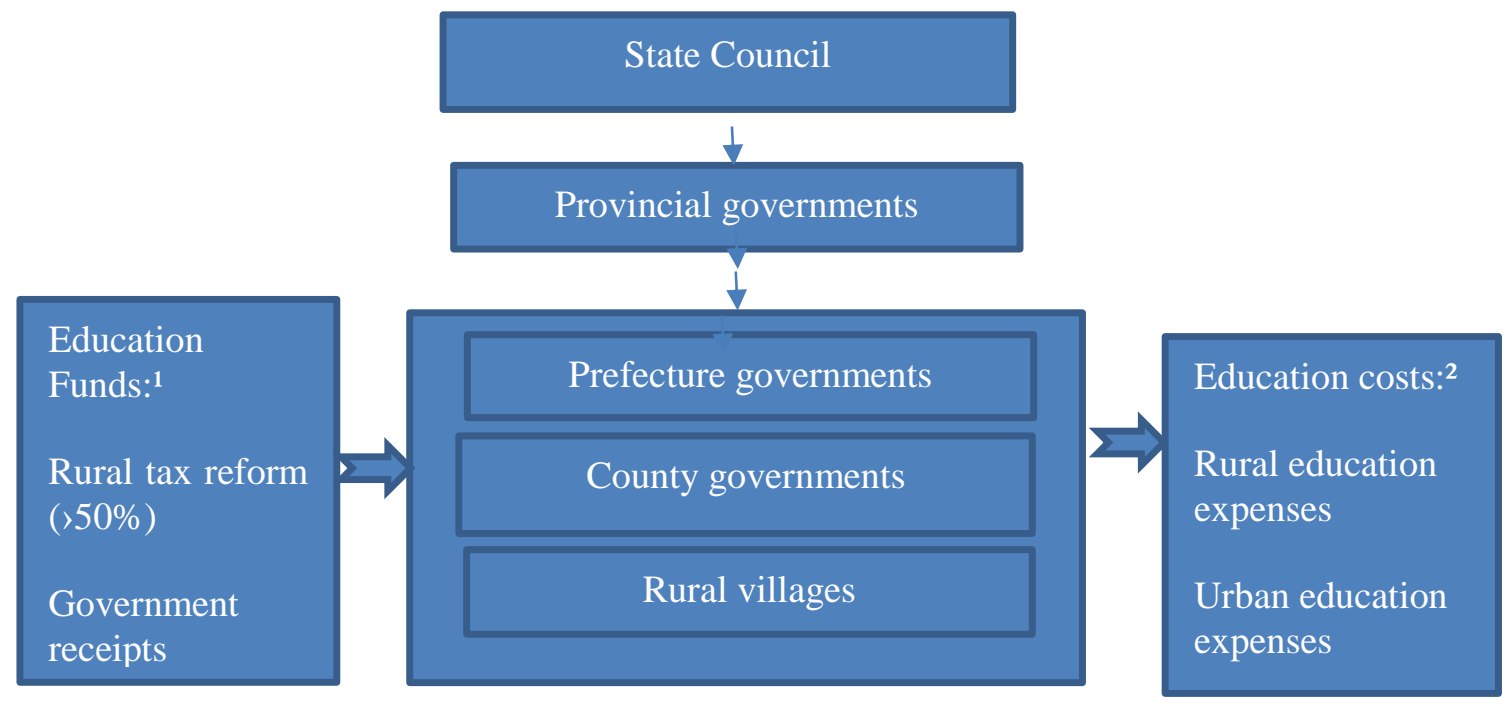

Figure 1: Administrative structure of the Chinese education system

${ }^{1}$ This refers to funds available for local governments.

2 This shows expenses that local governments shoulder.

The 13th entry of Decisions urges local governments to restructure schools by merging small poor ones with larger ones (generally located far from villages, presenting logistical challenges for rural families) with a subtitle, "adjust the school layout of rural compulsory education according to local needs" (SC 1998, 13). The general public and media referred to it as the "School Consolidation Policy" (SCP), meaning the closure and merger of small schools with large ones in urban areas, nationwide.

The intention of the policy, according to Decisions (SC 1998, 13), includes the equitable distribution of resources, greater economic educational efficiency and, supposedly, more balanced development in education. It is believed that grouping students into large well-equipped schools improves management and enhances quality, especially in rural areas (Liu et al. 2012; Zhao and Parolin 2011).

However, the implementation of the policy was hardly promising, given financial and administrative concerns. When township governments carry the responsibility for making up financial deficiencies with township revenues being used to manage local schools, they may use the SCP to justify the closure of schools to save funds (Shi and Zhao 2016). The correlation between the number of closed schools and the competitiveness of Chinese provinces shows that financially weaker provinces tend to close more schools to save funds and reallocate these to sectors that contribute more to the GDP, such as manufacturing (Ding and Zheng 2014). Parents have to bear more financial pressure because of longer commutes from home to consolidated schools (Yang 2010). High overheads (for parents) and long commutes (for children) have led 
to increased dropout rates among village pupils (Zhao and Parolin 2011), which contravenes the intentions of the SCP. Road safety is a risk, as traffic accidents with casualties have occurred involving packed school minibuses, which have caught national attention (CNTV 2012). Over-sized urban classes of 70-100 students have raised pedagogical difficulties in dealing with students' varied academic levels. The closure of rural schools has also led to the loss of certain local cultural features, including traditional arts, food, and festivals, and has caused instability in local communities, with increased divorce and crime rates (Fan 2006; Xiong 2007).

Following controversies around the SCP, the State Council adjusted the policy in 2012 to compel local governments to rebuild teaching centres and primary schools where necessary (SC 2012). This adjustment has been interpreted by the public as the end of the SCP era (CNTV 2012). In the media and academia, the SCP's consequences are widely discussed (as reflected in aforementioned literature). The central government has, since 2012, issued several administrative remedies to regulate boarding schools, support the mental health of left-behind children, and relocate primary schools, where necessary (SC 2016; 2018). Officials at different levels of government write "selfinspection" reports considering the causes, consequences, and remedies of the SCP. However, the pace of school closure has become hard to decelerate. From 2001 to 2012 there was a decrease of 49.4 million in rural student enrolment (see Table 1). The number of rural primary schools in China declined by 62.75\% between 2001 and 2012 (MoE 2002; 2013). In 2018, rural primary schools were still closing at a rate of 16 per day (Liwei 2018).

Table 1: The number of rural schools, new entrants and enrolment in 2001, 2012 and 2016 (across China) (MoE 2002; 2013; 2017)

\begin{tabular}{|l|l|l|l|}
\hline & $\mathbf{2 0 0 1}$ & $\mathbf{2 0 1 2}$ & $\mathbf{2 0 1 6}$ \\
\hline Primary schools & 416198 & 155008 & $*$ \\
\hline $\begin{array}{l}\text { External "teaching point" (a small } \\
\text { school, with only two or three } \\
\text { classes) }\end{array}$ & 110419 & 62544 & $*$ \\
\hline Classes & 2761251 & 1235725 & $*$ \\
\hline Graduates & 16223781 & 6242484 & 4322555 \\
\hline Entrants & 13118326 & 6572605 & 5171991 \\
\hline Enrolment (total) & 86018027 & 36524886 & 28917345 \\
\hline
\end{tabular}

* Data are not available for these cells.

Issues related to the SCP are frequently analysed macroscopically, at the level of the organisation, with developmental issues dominating discussion. There is, however, relatively little discussion of policy implementation in rural areas or the effects on rural 
children. The lives of rural students who have been affected by the SCP suggest poor quality education, unpleasant school experiences and long-suffering peasant parents. Peasants' voices are not generally heard, and they lack channels to speak for themselves; furthermore, the wider public is not generally known for its sympathy towards lower social groups. However, as this research shows, shifts in the meaning and focus of the $\mathrm{SCP}$, at all levels of government, contribute to the justification and legitimisation of the policy, making the closure of schools pervasive but unchallenged in ways that can alter the direction of the SCP.

This is part of a larger consideration of how collective conformity tends to run through the process of policy, as shown here. The different levels of government tend to justify the policy by framing its implementation as a task to satisfy the demands of the central government. Furthermore, age-long perceptions of rural residents as lacking personal ambition and enterprise (indicated by their lack of material success) and that sacrifice is necessary for advancement further silence rural communities, who reluctantly accept changes imposed on them. The SCP has not necessarily been implemented through coercion; rather, it has been imposed through the marginalisation of rural communities, which has been naturalised in political discourse in the current context of Chinese educational reforms, as has happened in other national contexts (see, for example, Sen 1999).

\section{Background}

Jikan is a village in north-western China (see Figure 1), located in the Huangtu Plateau, and it is used here to consider the effects of the SCP. It is isolated with one dirt road leading to the nearest town, 15 kilometres away. Wealthier villagers commute by motorised transport, while poorer villagers walk or take a free ride if they need to travel. The removal of Jikan Primary School left pupils with no choice but to live as boarders or in rented houses near town schools or to remain in Jikan and wake two to three hours earlier than usual to reach town schools. 


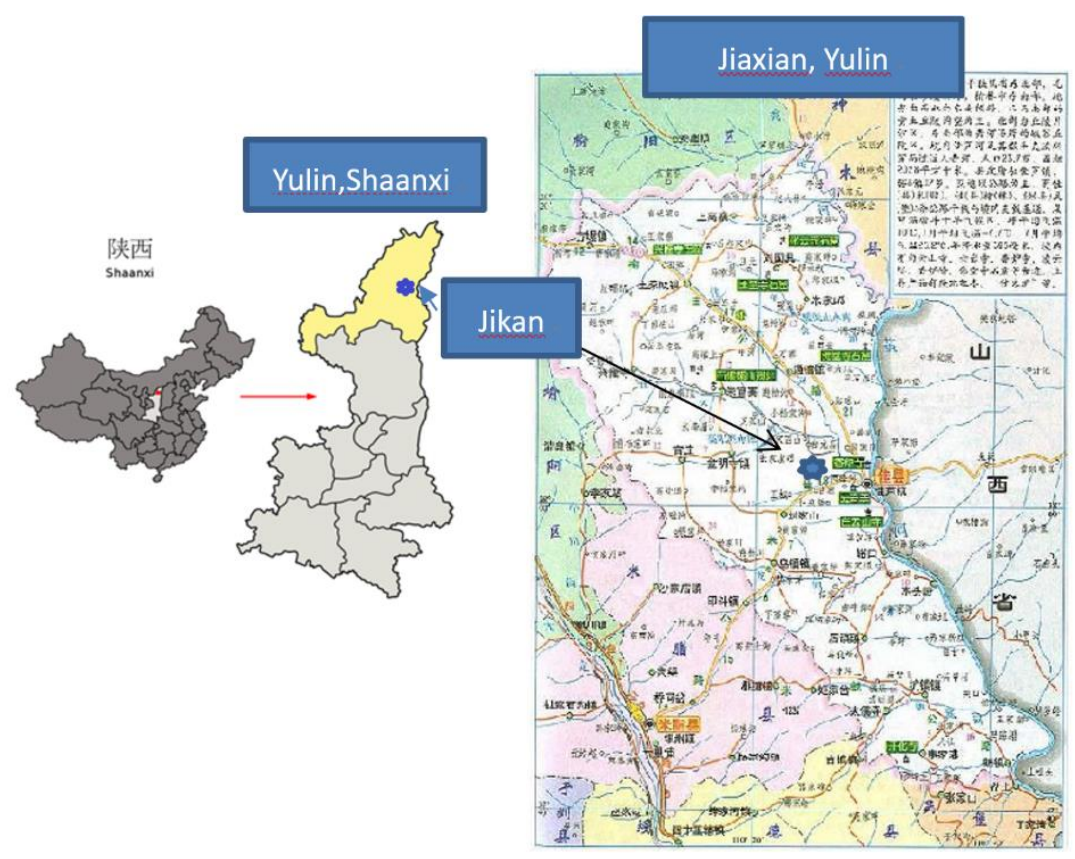

Figure 1: Jikan village in Shaanxi Province. The map shows China, Shaanxi Province, Yulin (prefecture), Jiaxian (county), and Jikan (village). Administrative divisions of China have five levels of local government: province (an autonomous region), prefecture, county, township, and village. Herein, the administrative division of the ethnography is Shaanxi province, Yulin prefecture, Jiaxian County and Jikan village)

Most Jikan residents live by manual farming and raising livestock. Dry soil and weather make only a few plants available to cultivate, including jujubes, wheat and potatoes. The steep slopes (see Figure 2a and $2 \mathrm{~b}$ ) restrict the use of modern farming equipment, e.g. combine harvesters. Most farms rely on manual labour or limited use of tractors. 

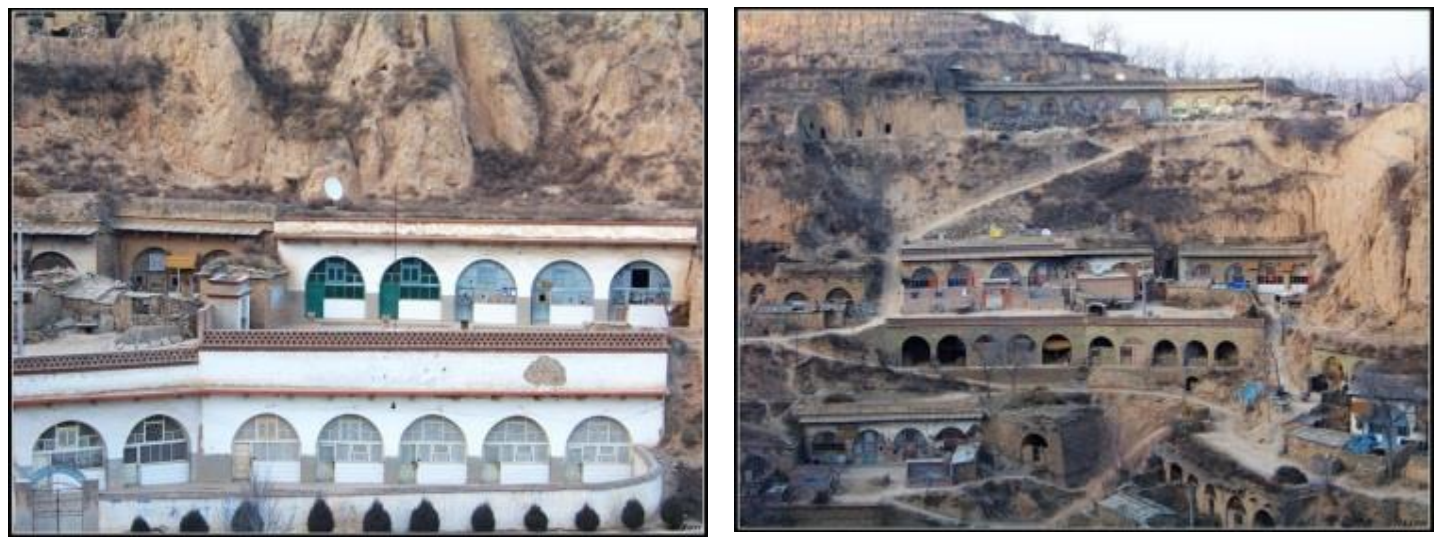

Figure 2a and 2b: Jikan village and its primary school

Rural and urban annual incomes in Jiaxian, where Jikan is situated, are 28\% and 24\% lower than in the nation overall (see Table 2), respectively, because the county is in north-western China, which relies largely on agriculture and is less developed than other parts of the country. However, Jiaxian County has a larger rural annual income per person than Jikan village, as those in Jikan mostly live on a national subsidy (around USD30 monthly), making their annual income rather low, overall.

Table 2: Annual income per person in Jikan and across Jiaxian (in Chinese RMB) ${ }^{1}$ (Jiaxian Government 2017)

\begin{tabular}{|l|l|l|l|l|l|}
\hline Year & $\begin{array}{l}\text { Annual } \\
\text { income } \\
\text { Jikaners }\end{array}$ & $\begin{array}{l}\text { Rural } \\
\text { annual } \\
\text { income } \\
\text { Jiaxian }\end{array}$ & $\begin{array}{l}\text { Urban } \\
\text { annual } \\
\text { income } \\
\text { Jiaxian }\end{array}$ & $\begin{array}{l}\text { National } \\
\text { rural annual } \\
\text { income }\end{array}$ & $\begin{array}{l}\text { National } \\
\text { urban annual } \\
\text { income }\end{array}$ \\
\hline 2006 & 1500 & 2127 & 8998 & 3587 & 11759 \\
\hline 2013 & 3900 & 7254 & 23810 & 8896 & 26955 \\
\hline 2016 & 5400 & 8893 & 25668 & 12363 & 33616 \\
\hline
\end{tabular}

From 2006 to 2016 the population of Jikan dropped from 467 to 124 (73.4\%), as much of the workforce moved elsewhere, joining the growing national trend towards migrant work. Jikan residents who migrate to towns earn more than those who remain in their village. In China, the number of migrant workers is increasing considerably (see Figure

$1 \quad 1 \mathrm{RMB}=$ approximately $0.16 \mathrm{USD}$ 
3) due to economic incentives, as their monthly net income is considerably higher than those of rural residents.

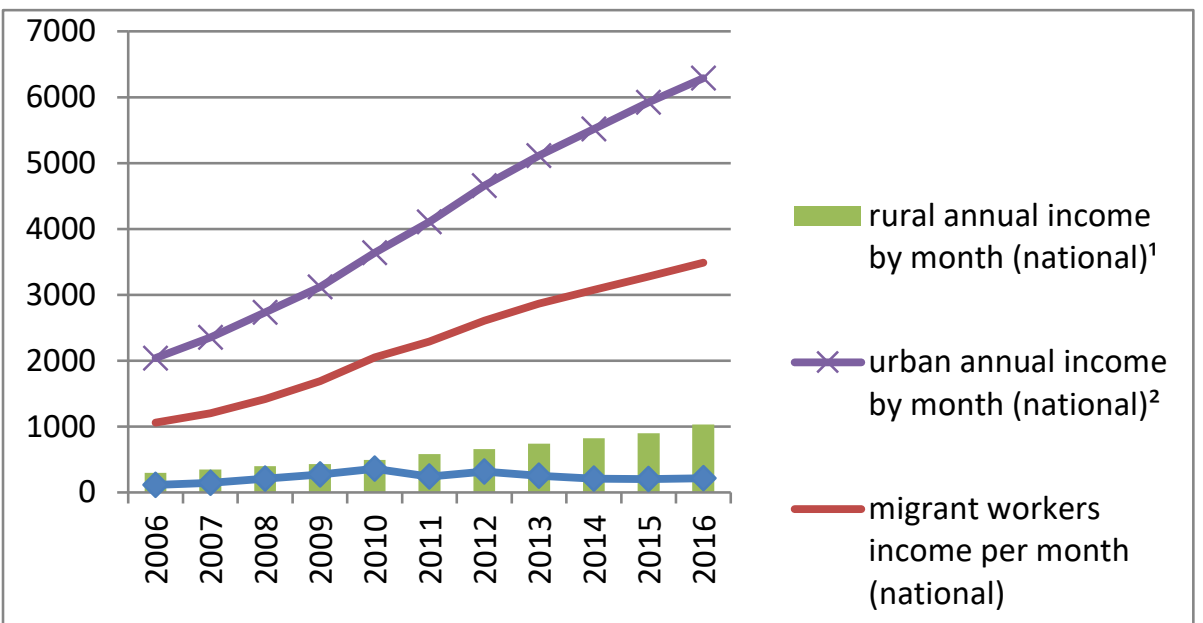

Figure 3: Migrant workers' net rural annual income and urban annual income per month (CNBS 2017). Figures are given in Chinese RMB

1. Rural annual income per month/12 (data available in Table 2)

2. Urban annual income per month/12 (data available in Table 2)

Jikan Primary School was a two-storey building (see Figure $2 \mathrm{a}$ and $2 \mathrm{~b}$ ). According to the village head, in the 1990s and early 2000s, there were at most nine teachers and 120 students at the school. Starting around 2001, enrolment decreased, as some children followed their parents to other counties when more rural parents sought better incomes in urban areas. When this study was conducted, in 2007, there were 25 students and three teachers at the school. Within Jikan, the school constituted a significant institutional setting, bringing together villagers for special events. Closed in 2008, it has since been used occasionally for storing crops at harvest time.

When this study was conducted (2007-2018), basic education was being restructured across China. This included the devolution of management, rising competition among schools, and readjustment of public school structures. In the arena of rural education, the SCP was meant to improve management capacity and enhance education quality. However, in many cases it led to mounting inequalities in the distribution of educational resources and the marginalisation of rural families. 


\section{Methodological Considerations}

Our connection to Jikan dates from 2007. From 2007 to 2017, the first author returned and stayed for 10 days each year. Between 2011 and 2017, research was conducted into English language education in Yulin, the prefecture where Jikan is located (Shi 2016). The resulting ethnographical research depicts social processes linked to language education in which many poor migrant children are deprived of social mobility as a result of the leverage of English in high-stakes national exams. Concomitantly, from 2016 to 2018, attention was directed towards Jikan villagers who have children in primary and junior middle schools, which were targeted by the SCP. Interviews were conducted among Jikan students and families to gain an understanding of their educational experiences. In the intervening period, there has been continuing interest in the educational experiences of Jikaners. Ethnography in this context is useful for exploring the lives, experiences and meanings constructed by rural community members (e.g. Liu et al. 2012).

The research follows a scholarly tradition of integrating critical discourse analysis (CDA) and ethnography, from critical framing to analysis and representation (Fairclough 1995; 2001; Krzyżanowski 2011; Sercombe 2010). Ethnography and CDA both have an interest in contextual impacts and power relationships embedded in language use (Shi 2015). CDA analyses discourse practices as socially constituted events to demystify discourse and power relations (Wodak 2009). Ethnography also focuses on tensions between structure and agency, or macro policy and micro agency power, in influencing policy implementation. Ethnography provides researchers with the means to analyse agency and roles that local practitioners manifest in policy processes; CDA provides a foundation for dealing with policy substance, and a focus on power and ideology in policies (Krzyżanowski 2011).

We adopt Fairclough's (1995) three-dimension model derived from the ethnography of communication. This recognises that each instance of discursive practice can be seen as a language text, and is situated within a broader social structure. The dimensions are interrelated: discourse is the link between the text and sociocultural practice, and how a text is produced and interpreted depends on sociocultural practices, of which language forms a part; discourse shapes the text and leaves "traces" in surface features. We consider Jikaners' interpretations of ways that macro-level policies impact the implementation of the SCP and how local policy interacts with macro-level policy. Also examined are relationships between texts (oral and written), practices, and broader political and social structures. Official texts are analysed, as are interviews conducted with local officials, teachers and villagers. Regarding the former, we show how texts contribute to the institution of rural education as part of larger sociological processes. We pay attention to textual devices that contribute to the justification of power and inequality. The purpose is to contextualise SCP texts and identify local adaptations between 2007 and 2018. 
The ethnography breathed life into the discourse analysis, focusing on the perspectives and practices of participants. The combination of CDA and ethnography allows one to see how discursive constructions of social practices interact over time and across contexts. It provides a foundation for understanding the recontextualisation of the SCP in local contexts, how this is related to policy texts, and what this means for Jikan's villagers.

\section{From Resistance to Conformity: Implementing the SCP in Jikan Village}

The following sections are structured around four episodes that mark critical junctures along the educational path of Jikaners, and also represent the SCP's process, from its emergence and interpretation to its subsequent implementation by local government proxies, in schools and local families. The respondents include the following: a.) the last groups of primary school children before the school was closed in 2008, including the 25 students in our 2007 study, as well as some who had transferred after the introduction of the SCP in 2001 (there was a decline in students from 2001: first, there were constant rumours that the school would be closed; second, teachers were transferred to town schools from 2001; and third, parents sought better incomes and left the village); b.) some Jikaners whose children used to attend Jikan village school, and c.) some parents who come from Jikan but currently live in other parts of Yulin and had children in primary school at the time of the study. The study then manifests the trajectory changes for Jikaners before and after the implementation of the SCP. Students and parents interviewed included only those who agreed to talk about their perceptions and experiences. The analysis demonstrates the inappropriateness of the SCP from the perspectives of some officials from lower levels of government, Jikaner students and their parents.

\section{Episode 1: "Our School Is Safe (from Being Closed)" (Interview with Jikan Village Head, 2007)}

The SCP is the 13th entry of Decisions (State Council 1998). The policy was printed and delivered to every education bureau across China for implementation. Then began the large-scale school closures, over a decade (outlined in section 2, above). In Shaanxi Province, various levels of government held meetings, wrote reports and arranged sessions to ensure the implementation of the SCP (SEB 2004; YEB 2005). Yulin, where Jikan is situated, was no exception, as 4278 rural schools and teaching centres were closed between 2001 and 2012.

Jikan Primary School was also partly affected by the SCP prior to its closure (in 2008). Some Jikan children, mostly males, moved to other counties with their parents. Boys are more likely to be allocated educational resources when parents decide which child to take with them to a city, where expenses are higher than in villages (cf. Duan et al. 2013; see also Lumadi [2012] regarding the South African context in which females are given less education opportunity than males, which further restricts their chances of social mobility). Among Jikan school students who graduated from junior middle 
school, girls are more likely to attend secondary professional schools or vocational middle schools where they learn skills to enter the workforce. Boys, however, generally have more chance of entering a senior middle school, increasing the possibility of entering higher education following a highly competitive national examination.

Jikan parents are aware that a schooling hierarchy exists; only when educational opportunities of higher status are unavailable do parents send their children to vocational schools. Education remains the exclusive means of social mobility for Jikan children. Parents' perceptions of their children's future success are typically based on getting into a university, and thereafter securing a decent government job, which is desirable due to its long-term security and benefits. Most Jikan parents of students who commute to middle schools agree that their children's schoolwork is very demanding. They use expressions such as "bear pain" and "endure bitterness" to describe the adversity in studying. The idea of "diligence for success" originates in Confucian thought whereby academic success requires suffering. An old Chinese saying states "only by enduring extreme pain can one become the upper class". This theme arises in many studies of the education-poverty trap (e.g. Brown and Park 2002; Ha and Yan 2018) in which it is found that poor rural students believe diligence will help them overcome their families' weak socioeconomic status. The parents in this study expressed support for their children's efforts and their own sacrifices, which are regarded as necessary to help achieve their children's future educational goals. As one parent explained:

Getting into a university is very hard ... I tell my kids: If you endure bitterness now, you will have a good life tomorrow. If you try to play around, you come back, raise goats and work on the farm. When you get into university, you will have a job. Everything will be all right ... We endured bitterness all for you. We cannot help more, but to feed you and provide clothes. You are the ones who study. (Notes 2007/08/04) ${ }^{2}$

Parents' sacrifices put further pressure on children (see Paine and Delany 2000). The middle school students from Jikan who were interviewed found schooling stressful. They mentioned that not failing their parents is a key reason for their diligence, followed by getting into a university and having a good future. Extensive government support is not expected because of a belief that "diligence for success" justifies the tremendous effort rural children must make to capitalise on opportunities to achieve success. Social mobility, however, is affected by other factors, including government policies, social welfare, educational opportunities, and local administrative choices.

Six teachers at Jikan primary school were transferred to town schools after the SCP was implemented elsewhere in Jiaxian County in 2001. Three substitute teachers stayed in Jikan. In rural China, substitute teachers generally have relatively low-quality education degrees and little if any teacher training experience (Sargent and Hannum 2009). When

2 Interviews and government policy texts were originally in Chinese and translated by the first author into English for the purpose of analysis. The translation has been checked by two professional translators. 
it emerged that certified teachers were difficult to retain, more Jikaners moved away to pursue better opportunities for their children. Several nearby schools were closed and many Jikaners worried about the future of their village school. As one parent commented:

Teachers stopped coming ... The school does not look like a school anymore. If it continued, it would be closed as well. Without a school, children would have to walk dozens of li to school. Who would pick them up? Who can afford for all of them to stay in student accommodation? (1 li = approximately 500 meters; Notes 2007/08/12)

Several parents talked to the government-appointed village head, who also had children at Jikan Primary School. He went to the county educational bureau and enquired at several offices, asking who was "in charge". He was subsequently chased away by a guard, who told him to wait for a "notice" and not to return otherwise. The village head told his fellow villagers to relax, as he assured them: "Our school is safe" (safe means anquan and that a school is exempt from being closed; interview with village head, 2007/08/12).

\section{Episode 2: "The Best Steel Should Be Used to Make the Edge of the Knife" (Interview with Local Education Officer, Mr Zhang, 2008)}

The SCP was initiated as the 13th entry in Decisions on Deepening Education Reform and Fully Promoting Quality Education (SC 1998, 13), subtitled, "readjustment of school layout of rural compulsory education according to local needs". The Chinese text is less than 200 characters:

According to the principle of proximity of primary schools, the relative concentration of junior middle schools, optimisation of educational resource allocation, there is a need to rationally plan and adjust the layout of schools. Under the premise of providing convenience for students to attend the nearest schools, rural primary schools and teaching points should be merged appropriately. In areas with inconvenient transportation, the necessary teaching points should be retained, to prevent the likelihood of student dropouts due to school restructuring. The layout of schools should be planned, together with: the renovation of dilapidated buildings, formalisation of academic norms, urbanisation development and migration relocation. The adjusted school buildings and other assets should be guaranteed to develop education. Where necessary, boarding schools should be opened.

According to the text, local governments were required to alter educational provision according to local needs, such as (in)convenience of the school commute, academic norms, and migrants' relocation. Yet, the text leaves much unsaid and lacks clear directives, leaving various policy vacuums. Shortly after it was issued, Decisions (SC 1998) was sent for review and implementation by lower levels of government. The Shaanxi Education Bureau (where Jikan is situated) issued several texts, and passed these to lower levels of government. The authors of Suggestions on Inspection of Shaanxi Province's Achievement in Promoting Basic Education, issued by an inspection 
team from the central government and the SEB, spoke highly of counties where the SCP had been implemented (SEB 2004, 4):

In accomplishing the national policy in developing basic education, county education bureaus can, under the request of provincial governments, carefully fulfil the task of adjusting school distribution, and better school conditions. For instance, Yanchuan County, according to the plan, adjusted the number of schools from 437 to 334. It accomplished the task of primary school adjustment. In Zhashui County, 15 senior schools were reduced to 10 , the average number of classes in schools increased from 6 to 12 , letting the junior middle school coverage increase from less than 10000 to 13700 ; 279 primary schools (with only Grade 1-3) were cut to 197, teaching points reduced from 350 to 269 .

The SEB (2004) has stated the provincial education bureau's alignment with the national government in accomplishing adjustments and further pronounced its power over county education bureaus, ensuring the closure of schools is a "task" that must be accomplished, rather than a locally tailored and negotiated policy. The text presupposes the factuality of a previous state of schools and positively evaluates changes brought about by the SCP, using language such as "carefully fulfil", and "better school conditions". While the policy is seen as regulatory, it is viewed as beneficial and an obligatory task for lower levels of government.

The provincial document was sent to every prefecture, county and township education bureau to "study" (SEB 2004, 1). In 2005, the Yulin Education Bureau (YEB) (the prefecture that administers Jikan), issued a document praising counties able to accomplish the task of closing many schools to "enlarge educational scale and efficiency, and optimize education resources allocation" (YEB 2005, 4). Between 2001 and 2012, the number of rural primary schools was reduced from 4827 to 549 in Yulin (YEB 2013), meaning only 11.4\% of local schools were retained (see Table 3).

Table 3: Schools and numbers of students in Yulin 2001 and 2012 (YEB 2013)

\begin{tabular}{|l|l|l|l|l|}
\hline Year & $\begin{array}{l}\text { Rural primary } \\
\text { school students }\end{array}$ & $\begin{array}{l}\text { Urban primary } \\
\text { school students }\end{array}$ & $\begin{array}{l}\text { Rural primary } \\
\text { schools }\end{array}$ & $\begin{array}{l}\text { Rural junior } \\
\text { middle schools }\end{array}$ \\
\hline 2001 & 449035 & 19456 & 4827 & 237 \\
\hline 2012 & 31878 & 40141 & 549 & 198 \\
\hline
\end{tabular}

It should be noted there were indications that local governments were under financial pressure to support local schools, caused by a shift in the burden of education supply to county governments (cf. Ding and Zheng 2014; also see the discussion above). The SEB $(2004,3)$ shows the government also relied partly on donations to cover deficiencies in funding: 
Comrades in Zhashui have altogether raised funds of over 219,000 RMB, among which 31,000 RMB was raised this year. They have set up a committee to send out an initial written proposal to raise funds, setting up moral steel to the fund-raisers and have created an enthusiastic trend in donation. ... Villagers have sacrificed a lot of their holidays to clean the building ... they have saved a lot of funds.

The discourse elides human participants from policy texts, supporting the implementation of the SCP and the unquestionable authority of the central government. In our study of the SCP in Jikan, vagueness can be seen in addition to the absence of accountability and due process. According to the procedures of the Jiaxian Education Bureau, a fact-finding visit should assess the necessity and feasibility of closing local schools. Government servicemen, in charge of basic education, were sent to villages to check the condition of the school. Mr Zhang, a serviceman from Yulin Education Bureau, was given the responsibility of implementing the SCP in Jikan, along with two colleagues. They went to Jikan Primary School to assess teaching quality, campus conditions, and the feasibility of the SCP.

According to villagers, the team stayed for a day, talked to the village management council, then left hurriedly. Questions were asked about the condition of the local school, including numbers of students, teachers, and classrooms, along with enrolment and dropout rates. There was no mention of implementing the SCP, according to the village head. Subsequently, the SCP was implemented in Jikan, without notice, in July 2008. In a meeting held for village heads in Jiaxian County, Jikan village's head was told by a county official to announce the news of the implementation and to "work with the villagers". Teachers and students were told to begin their autumn semester (September to January) in a town school (8 kilometres away), one month in advance.

In their study, Shi and Zhao (2016) found $79 \%$ of villagers were not consulted about when their schools were to be closed, a factor in villager dissatisfaction over the SCP. As might be expected, Jikaners showed a degree of objection, and gathered to write a protest letter. This was never sent, as no one was willing to take the initiative. The village head declined, as he felt obliged not to challenge the government, saying:

They came here and said that they were to check the school condition and asked questions about numbers of students and teachers. They never mentioned anything about closing or consolidating the school. We knew nothing when they decided to close the school. ... Villagers, with children in the school, certainly felt inconvenienced about the changes and how this would affect their children's trip to school. Many children are too young to be transferred. Even if they are provided with student accommodation, one would feel worrisome. ... Schools in other villages were closed, and it's the norm not to disobey. ... It won't work if you complain. (Notes 2008/8/22)

The SCP has become normalised for villagers and the wider populace, and is viewed as not to be challenged. However, the closure of a school reduces the chances of children attending any school, and means families who seek alternative school arrangements will 
likely be split up, or forced to move, incurring further hardship (see the discussion above and below), factors also mentioned by Xiong (2007), Yang (2010), Liu and Xing (2016). An informal interview with Mr Zhang (who led the implementation of the SCP in Jikan) was conducted. Questions about the imposition of the SCP in Jikan were addressed to Mr Zhang. There was no mention of villagers' circumstances as a result of the change. Jikan Primary School had, according to Mr Zhang, backward teaching conditions and a small number of students, which are considered key for the implementation of the SCP. There were confrontations with local villagers during the process of the SCP's implementation, but he kept saying that the closure of Jikan's school followed directives from above:

We did everything according to the instructions of the upper government, to enlarge education scale and efficiency.... Small schools like Jikan's are hard to keep. They have low education efficiency. Education resources are limited. ... The best steel should be used to make the edge of the knife. (Notes 2008/10/04)

Mr Zhang's interpretation of the SCP encapsulates three themes important to an understanding the SCP's implementation. First, the implementation has shifted from being a policy that considers local needs (as suggested in Decisions [1998]) to a matter of "must-do" (as shown by the interpretation among lower levels of government). Locallevel officials legitimised the closure of Jikan Primary School, aligning with the upper levels of government and following orders rather than accommodating parents' perceptions and needs regarding local educational provision. Second, rural schools are marginalised in daily discursive practices, which describe rural education as "backward" and "inefficient", as seen in the response of state proxies such as Mr Zhang. Third, when there was an apparent shortage of educational resources, the rationale was to redistribute these to larger urban schools. The metaphor "the best steel should be used to make the edge of the knife" is significant because it is underpinned by economic imperatives (as the metaphor shows), and places these above the needs of the rural poor. The metaphor serves as a device to naturalise the sacrifice of rural schools, economically speaking, and, the allocation of more resources to better schools, mostly in urban areas.

In the annual report of the Yulin Education Bureau (YEB 2009, 3), some counties, including the Jiaxian branch, were praised for "accomplishing the task" of "adjusting local schools" educational layout" and "reducing the number of schools according to its schedule". Using positive terms, such as "accomplishing" tasks in basic education, allows the bureau to sound authoritative, but blunts the truth that the decision results in considerable educational challenges for villagers affected by such decisions.

\section{Episode 3: "The Students Lack Discipline" (Interview with a Teacher in a School to Which Some Jikan Children Were Transferred, 2013)}

Following the closure of Jikan Primary School (2008), the remaining 25 Jikan students were moved to a town primary school on the outskirts of Jiaxian. Waking up at four or five o'clock in the morning for the long commute to school soon made it very difficult 
for some Jikan children, especially younger ones, to follow the school curriculum. Nearly every Jikan student interviewed recalled missing school regularly. They soon lagged behind in their studies, which meant that some of them (as well as their parents) gave up hope of entering middle school. In Jiaxian, the number of middle schools was cut from 10 to six, of which only one has a senior middle school branch, making competition to secure a place disproportionately challenging. By the end of 2011, the third year after Jikan Primary School's closure, of the last group of 25 children in Jikan Primary School in our 2007 study, 10 dropped out of primary or junior middle school. Unlike previous children in Jikan, who could at least complete their primary education in the village and had a chance of continuing their education, these left formal education early. Some returned home to help with farm work; others went to work as migrant manual labourers.

Some accommodation in Jiaxian was arranged for village students who lived too far away to commute to the nearest school. Over half of the 25 children from our 2007 study have experienced living in a primary school dormitory. According to a survey conducted by the Yulin Education Bureau in 2012, 49.35\% of rural Yulin primary school students out of 127189 and $47.6 \%$ out of 51269 rural middle school students stay in boarding schools or private houses (YEB 2013). For children between six and 15, living apart from their parents during weekdays or the whole semester was not a cheerful experience. Elsewhere in China, rural boarding students comprise around $40 \%$ to $60 \%$, and many have reported psychological issues (Zhou et al. 2005). Internet cafés attract these young pupils. Although the national government has banned those under 18 from these, the chance to make money from children prompts café owners to provide services for them surreptitiously. Some Jikan children, between 10 and 14, regularly use internet cafés, while some students have begun smoking and drinking.

The transfer of students from rural areas has meant some urban schools have become overcrowded, with more than 90 students in a class. Most schools have doubled or tripled the number of classes following the implementation of the SCP. The oversized schools with oversized classes have led to class management issues, and concomitantly lower teaching quality. One Jikan student commented:

We were stuffed in a room. Students sat in the classroom aisles and teachers could not walk around. ... They could not know what we were doing down there. ... You can read novels, eat or sleep. (Notes 2012/5/16)

Many teachers consider the poor educational backgrounds, diverse academic levels and discipline problems among migrant children as major difficulties in their classes. The situation becomes more severe when migrant parents cannot provide support, due to busy schedules and low educational levels. Below is an extract from an interview with one teacher, $60 \%$ of whose students have a migrant background (some Jikan children were transferred to the school between 2009 and 2013): 
Our students come from migrant worker families. ... These students have poor backgrounds. Most of them cannot keep up with the classes. ... Their parents, you know. I've been teaching students three years and I haven't seen most of them. ... They do not communicate with me. ... So the class is hard to manage. The students lack discipline. Habits of learning are poor as well. Students don't do homework carefully ... arriving at school late. They are not active in the classes. The parents are busy making money to raise the family. They don't understand the issues. (Notes 2013/5/19)

This episode, though initially easy to comprehend, encapsulates many issues related to the ways in which migrant children live and study in a city. Students from poor socioeconomic backgrounds experience bullying and social exclusion. Migrant worker children can be identified easily, since they generally appear with torn clothes and ragged schoolbags. They tend to be reticent, sitting in class quietly. When they speak, inaudibly or in a "strange" accent, other children tend to sneer. Some scholars have also reported psychological issues and difficulty with social engagement among migrant children in urban schools (e.g. Zhou et al. 2005).

These issues tend to affect negatively a school's performance. Sometimes migrant children are neglected by teachers, who refer to them as "retards", "stupid", or "lazy", and prioritise students with good academic grades who, mostly, are from urban backgrounds. Some teachers expressed dislike of migrant children, as they distract the attention of other pupils who are more likely to succeed at school and reflect well on teachers (cf. Ding and Zheng 2014).

For village students, the chances of academic success are reduced due to a range of negative factors, including parents' inability to provide enough financial or academic support. Among primary schools in Yulin, less than $10 \%$ of migrant students have audio material to accompany English textbooks, while the ratio is above $90 \%$ for other students of urban Hukou (household registration permit). Less than $10 \%$ of migrant students attend extra-curricular classes, while the ratio is over $70 \%$ in the best schools where urban students comprise 95\% of the enrolment (Shi 2016). Eighty per cent of migrant children have at least one parent working and living away from home and most are unable to gain a "distinction" in their final assessments in order to enter a middle school. Nearly $90 \%$ of students who fail their exams are from migrant worker backgrounds (Shi 2016).

\section{Episode 4: "They Have Got Used to Living without Us ... Children of Poor Families Become Self-Sufficient Early" (Interview with a Jikan Parent, 2018)}

The SCP was called into question in 2012. In a national document (SC 2012), the central government scolded local governments for "blindly implementing the SCP ... causing difficulties for rural students in getting a good quality education". In a Yulin Education Bureau report (YEB 2013, 4), the phrase "blindly implementing the SCP" was used to rebuke "some places", which passed the responsibility and blame to lower levels of government. Although mistakes have been admitted by the central government, there 
remains a lack of accountability, exemplified by scapegoating "some local governments" for its failings.

From 2014 to 2018 , the central government issued several policies to remedy mistakes made when the SCP was implemented. It issued directives that teaching points and schools should be rebuilt where necessary (SC 2012; 2018). In Yulin, 34 schools (18 in rural areas), 13 junior middle schools (10 in rural areas), 45 teaching points, and 27 primary schools were (re)opened from 2013 to 2015 (YEB 2015). Yet, the movement of students from rural to city areas and the relocation of migrant workers have meant the reduction of rural schools has continued. Rural students continue to pour into urban areas, resulting in schools becoming further overcrowded. Many renovated rural schools have been abandoned following reopening, as there are no students to attend them. Reports show that rural and county schools were put under pressure to keep students in school (CNWest 2016). For many villagers, educational incentives encourage them to send their children to urban schools for a better chance of academic success. Meanwhile, some parents who separate from their children, due to the imposition of the SCP, prefer to send their children to urban schools for better educational opportunities. One Jikan parent commented:

If I send my boy to the township school, he would stay in a boarding school. If I send him to the county school or to Yulin, he would live in a boarding school as well. I might as well send him to Yulin. It is better for his education. (Notes 2018/2/23)

In Jiaxian, and elsewhere in China, a special kind of service, called "agency parenting" or "trusteeship classes and houses", has become popular. It includes tutoring and boarding, collecting children from school, checking homework, cooking meals and attending parents' meetings. Despite being illegal, the service is increasing due to the widespread needs it caters for. The demands on parents, especially migrant workers, who are unable to provide adequate out-of-school care for children, the low quality of mainstream education in rural settings, the restrictions on rural students' access to education in urban areas and examination-oriented education are catalysts for the growth in "agency parenting". Fees vary from 150 to 2000RMB/yuan (USD23 to 310) per month, depending on the number of children in an agency's custody and the level of service needed. Most children under agency care live with agents, seeing their parents at weekends or during school holidays, while some might go home each day after homework has been checked and dinner consumed.

In one of the primary schools in Jiaxian, attended by many Jikan children, over half with a rural Hukou live in private boarding houses near schools. Elsewhere in China, the number of left-behind children, with one or both parents' living away from home, reached 9 million in 2016 (CNBS 2017). Recognising the problem, the national government began to regulate private boarding services (SC 2018), many of which are overcrowded and in a poor condition (see Figure 4). According to a boarding house 
owner, extended family members, mostly grandparents, collect children from the house every two weeks. Parents show up only to pay boarding fees (Notes 2017/10/14).

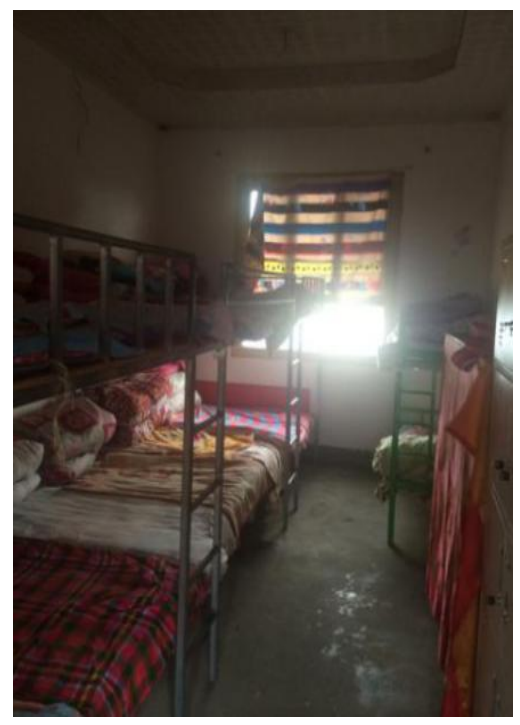

Figure 4: A cramped private boarding room

There has been considerable concern about young schoolchildren lacking adequate parental care, resulting in mental health issues, misbehaviour and poor performance at school (e.g. Zhou et al. 2005). Jikan parents seem to find the situation hard to change given their challenging circumstances. As one parent said:

They have got used to living without us. Children of poor families become self-sufficient early. Otherwise, what can we do? ... If you want to walk ahead of others, you need to make sacrifices. (Notes 2018/2/19)

Similar to those in our earlier study in 2007 (see Episode 1), educational opportunities and social mobility still rely on personal endeavour. "Children of poor families become self-sufficient early" is an old Chinese saying that has become normalised and hard to challenge. Wider contributing social factors, such as educational resources and opportunities, government policies, and community support, are not really considered salient factors.

\section{Discussion}

The four episodes presented illustrate key moments in Jikaners' educational paths during the implementation of the SCP, including during the conception of the policy, its local interpretation and implementation over the course of a decade, and its consequences, as perceived by those affected. The characteristics of the four episodes 
can be seen as interconnected. Together, the four episodes depict the circumstances of rural citizens, represented here by inhabitants of Jikan, who have been socially marginalised by the implementation of the SCP. The rural-urban divide contributed to the creation and proliferation of SCP implementation (Episode 1), and in turn aggravated inequality and marginalisation in rural education (Episode 2). This process does not necessarily occur through coercion but rather collective conformity, which is evident in levels of policy texts that contextualise SCP as beneficial and obligatory, and public perceptions of rural schools and communities as backward and inefficient and thus obliged to close down (Episode 2). The discursive and social practice of the SCP as a means of economising based on the notion of the backwardness of rural education (rather than on human costs such as villager satisfaction, family or mental health) further naturalises the marginalisation of rural students in the public education system under the discursive disguise of success through personal endeavour and sacrifice and through a de-emphasis on public support and social justice (Episode 3). A vicious circle emerges as the outcome of the SCP, contributing towards a wider rural-urban divide and reinforcing educational, sociocultural, and psychological gaps, which were further reinforced by rural parents' and students' naturalisation of their lowly social position (Episode 4).

First, Episode 1 spells out how the Chinese central government conceived, justified and tasked local governments with the implementation of the SCP. The children and parents affected by this policy understand the hierarchical nature of educational provision and the need for application and some degree of self-sacrifice in order to fulfil aspirations, but they also lobbied local village representatives to secure sufficiently accessible educational opportunities. The age-long perception of the causes of rural residents' marginality, which surfaces in the discursive disguise of success through personal endeavour and sacrifice, further silences the rural community and encourages them to accept, albeit reluctantly, changes imposed on them; it also overlooks the human cost of the SCP's implementation, in attempts to align local situations (through school closures) with national aspirations for greater fiscal efficiency.

However, in Episode 2 one can see that the SCP's interpretation and implementation by many local governments is understandable, given that the onus is on these state proxies to implement central government policies, as shown in certain discursive features of the SCP texts, including extensive use of modal operators and elision of human participation. These include examples such as "distribution should be rationally planned and adjusted" (SC 1998, 13) or "county governments should be under the supervision of provincial government to adjust school layout" (SEB 2004, 1). Modal operators in the SCP text involve the author's attitude towards the obligation to take action in the face of central government authority. The upper levels of government use modal forms to reproduce their authority, reflecting the absolute nature of institutional hierarchy across China. Using inanimate noun phrases, which Fairclough $(2001,141)$ refers to as "one genre of governance", such as "school distribution", "optimisation of educational resources allocation", and an "urbanisation process", the SCP texts create the 
impression that the policy has no human cost, without specific explanation as to the accountability of policy agents or who the beneficiaries are. Similar expressions abound in other policy documents (e.g. YEB 2005), legitimising the apparent necessity of implementing the SCP, and making the closure of schools pervasive but unchallenged in ways that can alter the direction of the SCP.

The schooling process in urban settings further separates rural and urban students, due to rural students' lower socioeconomic status, and other differentiating markers, including the ways in which rural students speak and dress. Additionally, poor schools' performances further reinforce their peripheralised positions and increase the onus on them academically, compounding dropout rates (which have increased with school mergers and mounting teacher indifference). Furthermore, rural migrant students face challenges related to parents with low academic levels, a lack of friends among children at urban schools, and, consequently, poor levels of integration at school (Gao et al. 2019). A vicious circle emerges, contributing towards a lack of socioeconomic progress. This is reinforced by rural parents' and students' naturalisation of their lowly social position, despite their unhappiness with the effects of the SCP and the lack of consultation between state representatives and villagers about changes in educational provision.

In Episode 3, one can notice further effects of the SCP, such as the overcrowding of urban schools due to the migration of rural families seeking better alternative educational opportunities. Other consequences include the challenges that teachers encounter in the face of overcrowded classes and the negative effects on some urban schools, as well as migrant children, who often lack family support mechanisms due to low levels of education and poor financial circumstances.

In Episode 4, one can notice the Chinese central government attempting to repair the effects of the SCP by reopening some local schools. However, at this point, many local parents had already migrated to cities and many refurbished local schools remained redundant. One can see further outcomes of the SCP whereby private provision had sprung up in various forms, such as "agency parenting" and "private boarding services", to make up for the shortfall in government provision.

The SCP has unnecessarily created a perception of the rural as "backward" and needing "modernisation", exacerbating differences between rural communities and urban society. The idea of "modernity in education" has contributed to an ideology where opportunities for educational success have become citizens' responsibility, and rural education is seen as a relatively low priority for the state. The SCP echoes what Cummins (2000) has argued regarding the ways in which dominant groups around the world have historically organised educational systems to reinforce social differences and maintain the social status quo, rather than promote social mobility. The widening gap between the rich and the poor is a major challenge identified in the educational literature. The education-poverty trap is a challenge faced internationally. For example, 
Lumadi $(2012 ; 2014)$ reports situations where rural South African children, especially girls, are deprived of quality education as a result of long school commutes, poor facilities and unqualified teachers. Setlhodi-Mohapi and Lebeloane (2014) find that the poor quality of school management teams can further contribute to the underperformance of previously disadvantaged schools that serve learners from predominantly poor communities. Motsa and Morojele (2017) show how vulnerable rural children in Swaziland, especially orphans of HIV/AIDS parents, are discriminated against. In Korea, Kim (2017) finds that limited opportunities and deprived circumstances restrict rural children's aspirations; they and their parents express feelings of abandonment and disappointment due to social exclusion and limited access to educational resources.

The results of these studies are similar, with the rural-urban divide reinforcing educational, sociocultural, and psychological gaps between children from different geographical backgrounds, engendering negative climates in classrooms and society, and increasing the chances of maintaining cyclical intergenerational poverty. As UNESCO $(2013,36)$ suggests, efforts need to be made "to ensure that resource allocation is equitable, predictable and sustainable ... [especially for] those who need them most, such as poor and vulnerable population groups". Thus, more investment in rural and migrant schools is needed (Lai et al. 2014). This research then echoes the importance of social justice in education (see Gebremedhin and Joshi 2016; Hackman 2005; Sampaio and Leite 2018). Otherwise, the invisibility of education inequality persists and continues to support larger, somewhat oppressive structures in society.

\section{Conclusion}

In this article, the educational landscape in Jikan has been outlined. Its significance resides in giving voice to stakeholders, especially parents, children and teachers, as well as local officials caught between demands from above and the needs of poorly educated and represented rural citizens. The article drew on critical discourse analysis and ethnography in order to review trajectories and critical junctures that shape educational change in Jikan, as an example of broader educational changes occurring across China. We paid attention to the local adaption of the SCP in the discursive practices of different levels of government and what villagers in rural China endure to capitalise on educational opportunities and secure some mobility. We concluded that the SCP has unnecessarily exacerbated the rural-urban divide. The SCP has not necessarily been implemented through coercion or enforcement; rather, it has been imposed through being naturalised and reinforced in political discourse and everyday practices in the current context of Chinese educational reforms.

\section{References}

Brown, P. H., and A. Park. 2002. "Education and Poverty in Rural China". Economics of Education Review 21 (6): 523-41. https://doi.org/10.1016/S0272-7757(01)00040-1. 
CNBS (China National Bureau of Statistics). 2017. "Per Capita Annual Income of Residents". China National Bureau of Statistics Database. Accessed June 23, 2020.

http://www.stats.gov.cn/tjsj/ndsj/.

CNTV (China Internet TV Review). 2012. "School Consolidation Policy: For Whom Was It Created?" Think Again, May 21. Accessed June 23, 2020.

http://news.cntv.cn/special/thinkagain/ruralschool/.

CNWest. 2016. "Investigation of Shaanxi Rural Schools: Be Aware of the Consequences of the School Consolidation Policy”. May 9. Accessed June 23, 2020.

http://news.cnwest.com/content/2016-05/09/content_13818800.htm.

Cummins, J. 2000. Language, Power and Pedagogy: Bilingual Children in the Crossfire. Cleveland, OH: Multilingual Matters. https://doi.org/10.21832/9781853596773.

Ding, D., and F. T. Zheng. 2014. "Location Difference, Promotion Criteria and School Consolidation Policy: Based on 1996-2009 Provincial Data". Journal of Development Research 6: 80-84.

Duan, C. R., L. D. Lu, J. Guo, and Z. P. Wang. 2013. "The Basic Living and Development Condition of Chinese Left-behind-Children: Based on the Sixth National Survey". Population Journal 3 (35): 37-49.

Fairclough, N. 1995. Critical Discourse Analysis. Boston, MA: Addison Wesley.

Fairclough, N. 2001. Language and Power. 2nd ed. London: Longman.

Fan, X. Z. 2006. "Studies on the Reason, Motivation and Pattern Selection of Adjusting Primary and Secondary School Distribution in Rural Areas". Education and Economy 82 (1): 26-29.

Gao, S., M. Yang, X. Wang, W. Min, and S. Rozelle. 2019. "Peer Relations and Dropout Behavior: Evidence from Junior High School Students in Northwest Rural China". International Journal of Educational Development 65: 134-43. https://doi.org/10.1016/j.ijedudev.2018.04.001.

Gebremedhin, A., and D. Joshi. 2016. "Social Justice and Human Rights in Education Policy Discourse: Assessing Nelson Mandela's Legacy”. Education as Change 20 (1): 172-98. https://doi.org/10.17159/1947-9417/2016/899.

Ha, W., and F. Yan. 2018. "Does Money Matter? The Effects of Block Grants on Education Attainment in Rural China: Evidence from Intercensal Population Survey 2015". International Journal of Educational Development 62: 174-83. https://doi.org/10.1016/j.ijedudev.2018.03.002.

Hackman, H. W. 2005. "Five Essential Components for Social Justice Education”. Equity and Excellence in Education 38 (2): 103-9. https://doi.org/10.1080/10665680590935034. 
Jiaxian Government. 2017. “Annual Reports on Socioeconomic Development”. Accessed May 1, 2018. http://www.sxjiaxian.gov.cn/dynamicShow-id-17005155.

Kim, H. K. 2017. “Transformative Educational Actions for Children in Poverty: Sen's Capability Approach into Practice in the Korean Context". Education as Change 21 (1): 174-92. https://doi.org/10.17159/1947-9417/2017/2338.

Krzyżanowski, M. 2011. "Ethnography and Critical Discourse Analysis: Towards a ProblemOriented Research Dialogue”. Critical Discourse Studies 8 (4): 231-38. https://doi.org/10.1080/17405904.2011.601630.

Lai, F., C. Liu, R. Luo, L. Zhang, X. Ma, Y. Bai, B. Sharbono, and S. Rozelle. 2014. "The Education of China's Migrant Children: The Missing Link in China's Education System". International Journal of Educational Development 37: 68-77. https://doi.org/10.1016/j.ijedudev.2013.11.006.

Liu, J., and C. Xing. 2016. "Migrate for Education: An Unintended Effect of School District Combination in Rural China". China Economic Review 40: 192-206. https://doi.org/10.1016/j.chieco.2016.07.003.

Liu, M., Z. Xu, F. Su, and R. Tao. 2012. "Rural Tax Reform and the Extractive Capacity of Local State in China”. China Economic Review 23 (1): 190-203. https://doi.org/10.1016/j.chieco.2011.10.002.

Liwei, W. 2018. "16 Rural Primary Schools Disappear Per Day. Who Would Care about the Future of Rural Kids?” 21st Century Education Research Institute, May 29. Accessed June 23, 2020. https://mp.weixin.qq.com/s/blsk7XwHWjEbE1EX-X72CA.

Lumadi, M. W. 2012 "Empowering the Voiceless Rural Women: A Daunting Task in African Society". Studies of Tribes and Tribals 10 (2): 123-30. https://doi.org/10.1080/0972639X.2012.11886650.

Lumadi, M. W. 2014. "Reversing the Trend of Dismal Performance in Disadvantaged Schools: A Curriculum Evaluation Exercise”. Mediterranean Journal of Social Sciences 5 (6): 24349. https://doi.org/10.5901/mjss.2014.v5n6p243.

MoE (Ministry of Education of the People's Republic of China). 2002. "National Statistics on Basic Education of Year 2001". Accessed June 23, 2020. http://www.moe.gov.cn/s78/A03/moe_560/moe_567/moe_587/.

MoE (Ministry of Education of the People's Republic of China). 2013. "National Statistics on Basic Education of 2012". Accessed June 23, 2020. http://www.moe.gov.cn/s78/A03/moe_560/s7567/.

MoE (Ministry of Education of the People's Republic of China). 2017. "National Statistics on Basic Education of 2016". Accessed June 23, 2020. http://www.moe.gov.cn/s78/A03/moe_560/jytjsj_2016/2016_qg/index_3.html. 
Motsa, N. D., and P. J. Morojele. 2017 "Narratives of Resilience among Learners in a Rural Primary School in Swaziland”. Education as Change 21 (1): 155-73. https://doi.org/10.17159/1947-9417/2017/1081.

Paine, L., and B. DeLany. 2000. "Rural Chinese Education: Observing from the Margin". In The Ethnographic Eye: Interpretative Studies of Education in China, edited by J. Liu, H. A. Ross and D. Kelly, 97-122. New York, NY: Falmer Press.

Sampaio, M., and C. Leite. 2018. "Mapping Social Justice Perspectives and Their Relationship with Curricular and Schools' Evaluation Practices: Looking at Scientific Publications". Education as Change 22 (1): 1-22. https://doi.org/10.25159/1947-9417/2146.

Sargent, T. C., and E. Hannum. 2009. "Doing More with Less: Teacher Professional Learning Communities in Resource-Constrained Primary Public Schools in Rural China”. Journal of Teacher Education 8 (3): 258-76. https://doi.org/10.1177/0022487109337279.

SC (State Council). 1998. State Council's Decisions on Deepening Education Reform and Fully Promoting Quality Education. Accessed June 23, 2020. http://www.jyb.cn/info/jyzck/200602/t20060219_10716.html.

SC (State Council). 2012. "State Council on Promoting the Balanced Development of Compulsory Education”. Accessed June 23, 2020. http://www.gov.cn/zwgk/201209/07/content_2218783.htm.

SC (State Council). 2016. "State Council's Suggestions on Strengthening the Caring of Rural Left-Behind Children". Accessed June 23, 2020. http://www.gov.cn/zhengce/content/201602/14/content_5041066.htm.

SC (State Council). 2018. "State Council's Suggestions on Strengthening the Building of Small-Scale Schools and Boarding Schools in Rural Areas". Accessed June 23, 2020. http://www.gov.cn/zhengce/content/2018-05/02/content_5287465.htm.

SEB (Shaanxi Education Bureau). 2004. Suggestions on Inspection of Shaanxi Province's Achievement in Promoting Basic Education. Xi'an: Shaanxi Education Bureau.

Sen, A. 1999. Development as Freedom. Oxford: Oxford University Press.

Sercombe, P. G. 2010. "Language and Education: The Experience of the Penan in Brunei". International Journal of Educational Development 30 (6): 625-35. https://doi.org/10.1016/j.ijedudev.2010.05.001.

Setlhodi-Mohapi, I. I. and L. O. Lebeloane. 2014. "The Role of School Management Teams in Underperforming Schools: A Matter of Values". Mediterranean Journal of Social Sciences 5 (3): 475-83. https://doi.org/10.5901/mjss.2014.v5n3p475.

Shi, J. Y. 2015. "The Combination of Critical Discourse Analysis and Ethnography in Language Policy and Planning Study: A Literature Review”. ARECLS 12: 119-37. 
Shi, J. Y. 2016. "English Language Education Policy in China: An Ethnographic Study”. PhD diss., Newcastle University.

Shi, Y. B., and X. X. Zhao. 2016. "The Reorganization of the School Consolidation Policy from the Peasants' Perspectives: Based on the Research Data from Rural Areas in Shaanxi, Ningxia, Qinghai'. Journal of China's Agriculture University 7: 28-36.

UNESCO (United Nations Educational, Scientific and Cultural Organisation). 2013. UNESCO Handbook on Education Policy Analysis and Programming. Volume 1: Education Policy Analysis. Bangkok: UNESCO.

Wodak, R. 2009. "What CDA Is About: A Summary of Its History, Important Concepts and Its Developments". In Methods of Critical Discourse Analysis, edited by R. Wodak and M. Meyer, 1-13. London: Sage. https://doi.org/10.4135/9780857028020.n1.

Xiong, X. M. 2007. "Reflection on the Present Adjustment of Primary and Secondary School Distribution in Rural Areas". Education and Economy 82 (2): 50-53.

Yang, L. 2010. "Reviews and Reflections upon the Policy of School Mapping Restructure". In Blue Book of Education: Annual Report on China's Education, edited by L. Yang, 73-85. Beijing: Social Science Academic Press.

YEB (Yulin Education Bureau). 2005. Suggestions on Promoting Yulin Rural Compulsory Education System. Yulin: Education Bureau Office.

YEB (Yulin Education Bureau). 2009. Annual Report of Basic Education Development in Yulin (2008). Yulin: Education Bureau Office.

YEB (Yulin Education Bureau). 2013. Self-Inspection of the Balanced Development of Compulsory Education in Middle and Primary Schools. Yulin: Education Bureau Office.

YEB (Yulin Education Bureau). 2015. Annual Report of Basic Education Development in Yulin (2014). Yulin: Education Bureau Office.

Zhao, D., and B. Parolin. 2011. "School Mapping Restructure in China: What Role for the Small Rural School?" Frontiers of Education in China 6 (2): 248-78. https://doi.org/10.1007/s11516-011-0131-5.

Zhou, Z. K., X. J. Sun, Y. Liu, and D. M. Zhou. 2005. "The Mental Development and Education of Rural Left-behind-Children”. Journal of Beijing Normal School University 1: 71-79. 